http://journal.uinsgd.ac.id/index.php/biodjati

\title{
BIRD DIVERSITY: THE POTENTIAL OF AVITOURISM RESERVES FOR BIRD CONSERVATION IN CURUP TENANG, SOUTH SUMATERA, INDONESIA
}

\author{
Fajar Islam Sitanggang1*, Mokhamad Asyief Khasan Budiman², Andy Afandy ${ }^{3}$
}

Received : September 15, 2020

Accepted : October 29, 2020

DOI: 10.15575/biodjati.v5i2.9537

${ }^{1}$ Department of Biology, Faculty of Science Institut Teknologi Sumatera, J1. Terusan Ryacudu, Way Hui, Jati Agung, Lampung Selatan DistrictPostal Code 35365

${ }^{2,3}$ Center for Coastal and Marine Resources Studies, Institut Pertanian Bogor (IPB University), Jl Raya Pajajaran No. 1, Kampus IPB Baranangsiang, Tegallega, Kecamatan Bogor Tengah, Kota Bogor, Jawa Barat 16172

e-mail:

*lfajar.sitanggang@bi.ac.id

${ }^{2}$ asyief.khasan@gmail.com

3aafafandy@pksplipb.or.id

*Corresponding author
Abstract. Birds have a fairly wide living habitat, including waterfalls. Curup Tenang is a waterfall tourism site which has a wildlife habitat suitable for birds. In The Curup Tenang tourism site, the number of visitors has decreased over years. Birds are one of the wildlife animals that have ecological values, potential tourism, and cultural values. The diversity of birds in this tourist location have not been recorded. Meanwhile, by increasing knowledge and databases regarding the diversity of birds in this area can be an additional reference for the development strategy in the Curup Tenang tourism site so that it becomes a distinctive attraction for visitors. This study aimed to determine the diversity of birds that never been recorded before and to conduct a potential support of avitourism activities. The results of this study can be used as a guideline to study the potential of avitourism. The diversity of birds found in Curup Tenang consisted of forty-eight species belong to twenty-seven families, while three of them cited as protected bird species. This study concluded that Curup Tenang contains a high diversity of birds and it has a great potential to be developed into an attraction of tourism.

Keywords: avitourism, bird diversity, conservation, Curup Tenang, waterfall

\section{Citation}

Sitanggang, F. I., Budiman, M. A. K. \& Afandy, A. (2020). Bird Diversity: The Potential of Avitourism Reserves for Bird Conservation in Curup Tenang, South Sumatera, Indonesia. Jurnal Biodjati, 5(2), 249-258.

\section{INTRODUCTION}

The largest economic sector that accounts for around $10 \%$ of the global Gross Domestic Product (GDP) is tourism. Tourism is one of the economic enforcers that has a large impact on the natural environment (Buckley, 2011). Tourism activities wield negative impacts in the form of changes in land use from infrastructure development, the impact of greenhouse gas emissions from air travel, and the entry of invasive species in an area (Buckley, 2011). Thus, solution needed for these problems, namely the concept of ecotourism. The rapid growth of mass tourism which has a negative impact on the environment gives rise to the increasing concept of ecotourism (Sriarkarin \& Lee, 2018). Ecotourism is defined as a responsible tourism trip to the natural environment, thus becoming an environmental conservation tool. The potential of ecotourism must be assessed before 


\section{JURNAL BIDDJATI}

http://journal.uinsgd.ac.id/index.php/biodjati

the development of ecotourism in order to understand local and community resources (Tseng et al., 2019). Ecotourism, by default and by design, has differentiated its product from other tourism products by focusing on three core criteria: nature, education, and sustainability. The opening of a new potential ecotourism site must consider the location, accessibility, infrastructure, services, and abundance of natural resources in a location (Yan et al., 2017). Green space is very important for the conservation of biodiversity, especially for bird species assessment (Liu et al., 2019). Moreover, ecologically sensitive, and visitor-control measures are needed to guarantee the sustainable development of potential ecotourism. However, many ecotourism developments fail due to a lack of proper assessment (Lonn et al., 2018).

The tourism sector that undergoes developmentin the South Sumatera region is The Curup Tenang waterfall in Bedugung Village, Tanjung Agung District, Muara Enim Regency. This tourist attraction is supported by the beauty of the waterfall with a height reaching $99 \mathrm{~m}$. However, the beauty of the waterfall only is not enough to increase the number of visitors to visit the site. It is recorded that during 2018-2019 there was a decline in the number of visitors. Therefore, alternative attractions need to be added to increase the value of tourism by enriching tourist activities. One of the potential attractions is avitourism or bird-watching-based tours, watching various kinds of birds with attractive colors and behaviors in their natural habitat. Based on the environmental conditions, Curup Tenang is a potential habitat for birds. However, the analysis of bird diversity in Curup Tenang has not been carried out. According to Lee et al. (2009), bird observation, in general, can be raised from bird diversity analysis. Therefore, the purpose of this study was to determine the diversity of birds and their potential for the development of avitourism-based tourism in Curup Tenang.

\section{MATERIALS AND METHODS}

This research was located in Curup Tenang in Bedugung Village, Tanjung Agung District, Muara Enim Regency, South Sumatera (Figure 1).

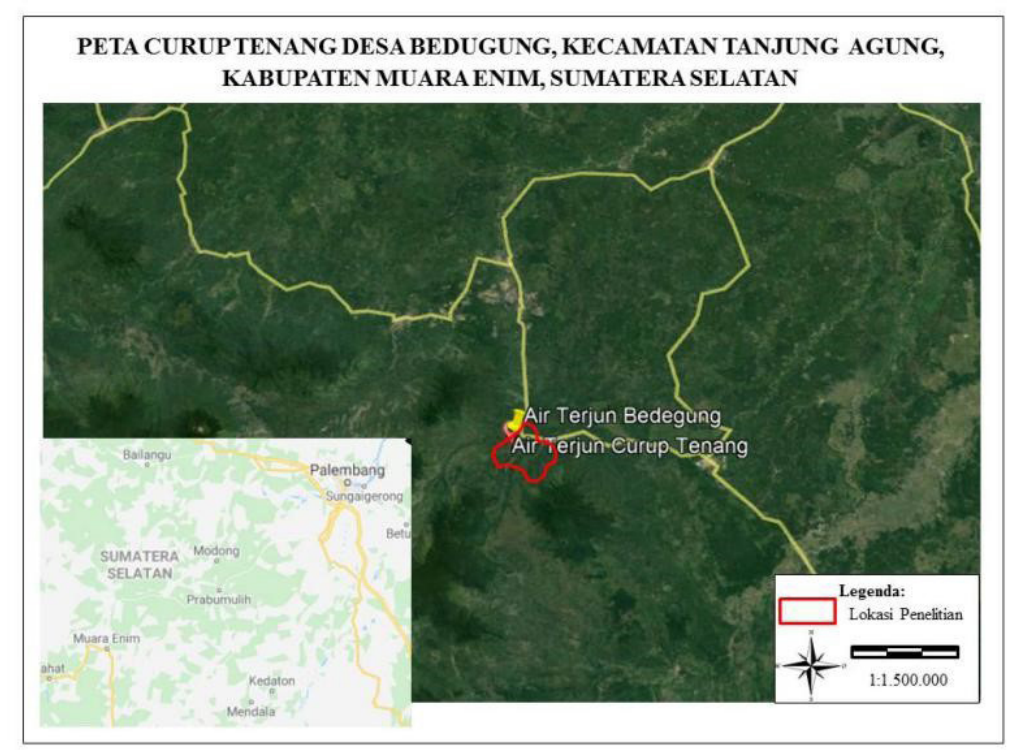

Figure 1. Research Location 


\section{JURNAL BIDDJATI}

http://journal.uinsgd.ac.id/index.php/biodjati

The method used in this study was the exploration method, in which data collection was carried out by observing through the paths in each research location to explore the diversity of birds in the Curup Tenang area and its surroundings in August 2018 and August 2019. The research was conducted by observing bird when the bird is active during the day as the bird is a diurnal animal. The time of the study was 07.00-17.00 WIB. The tools used in this study were binoculars, cameras, SKJB bird handbooks (Sumatera, Kalimantan, Java, and Bali), digital cameras, and stationery.

The analysis conducted in this research was a descriptive analysis based on the variables of species found, that identified based on the morphology of birds that appear, the sound, and guild composition. The descriptive analysis method aimed to provide an explanation in the form of a description based on data and information obtained during the research. The descriptive analysis definesas a procedure for solving problems by describing the state of the subject or object of research based on the facts that appear and explaining the relationships between all aspects studied. The qualitative research design used in this study aimed to conduct an in-depth investigation with a science-socio-cultural approach (Mardalis, 2008). In addition, there is an analysis stage regarding conservation status (level of threat according to the IUCN red list / The International Union for Conservation of $\mathrm{Na}$ ture, international trade status according to CITES / Convention on International Trade in Endangered Species of Wild Fauna and Flora, and protection status based on Government Regulations Republic of Indonesia PP No. 7 of 1999 cq LHK Regulation No. P.106 in 2018).

\section{RESULTS AND DISCUSSION}

Birds are the most common animals found on all land on earth. Bird existence is an important component in an ecosystem. Its role in helping pollination, controlling of plant pests, as well as balancing the food chain are the main things that need attention. So that birds can function as bio-indicators of environmental health. In that process, to measure the health of the environment it is necessary to collect data at some locations.

Birds found during the study were 48 species consist of 27 families (Figure 2). Birds need some supporting factors to survive and support their life, such as suitable habitat conditions, safe from disturbance, and food resources to replenish their energy.

Species of birds from Sylvidae and Cuculidae family were the most commonly found. The type of sylvidae family that often arise were Yellow-bellied Warbler (Abroscopus superciliaris), Ashy Tailorbird (Orthotomus ruficeps), Common Tailorbird (Orthotomus sutorius), Bar-winged Prinia (Prinia familiaris), and Yellow-bellied Prinia (Prinia flaviventris). Furthermore, the types that emerge from the Cuculidae family were Lesser Coucal (Centropus bengalensis), Hodgson's Hawk-Cuckoo (Cuculus fugax), Square-tailed Drongo-cuckoo (Surniculus lugubris), Western Koel (Eudynamys scolopaceus), and Plaintive Cuckoo (Cocomantis merulinus). Biodiversity of birds can be linked-to landscape heterogeneity, which, in turn, can be informative for management and conservation purposes. Biodiversity indicators can be a useful tool to assess biodiversity status, in the function of landscape heterogeneity (Morelli et al., 2013). 


\section{JURNAL BIDDJATI}

http://journal.uinsgd.ac.id/index.php/biodjati

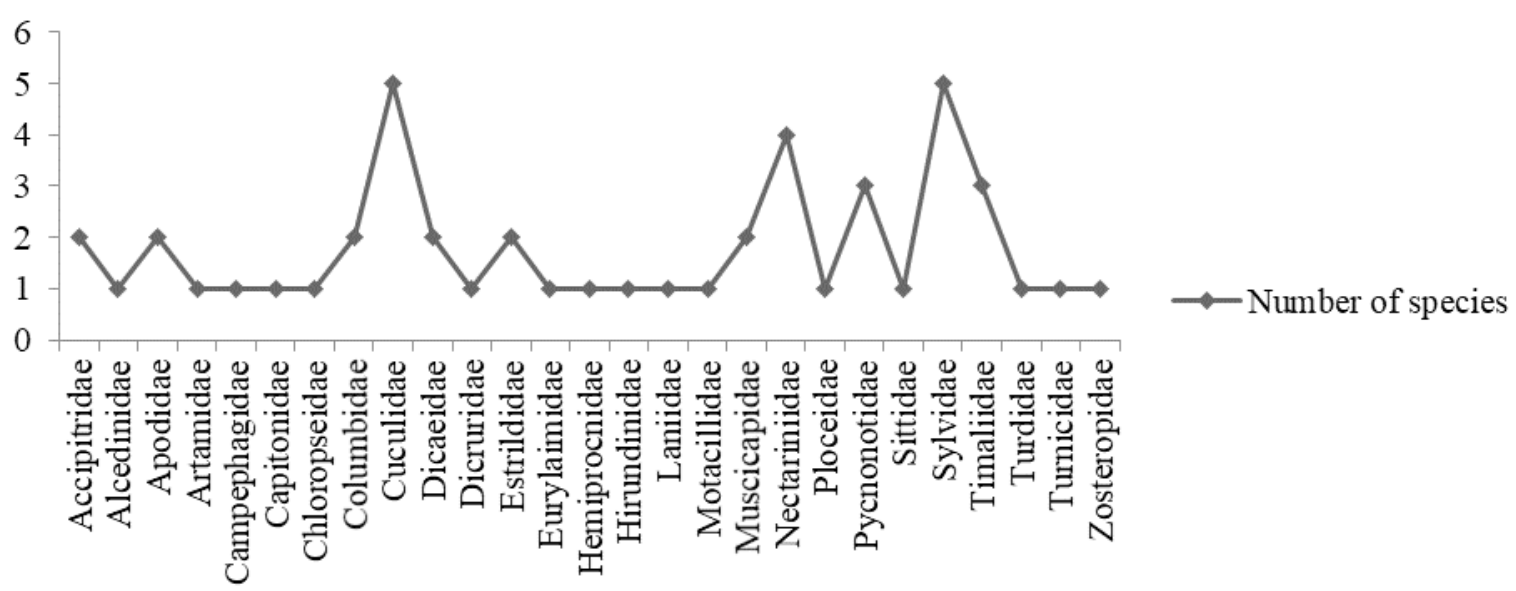

Figure 2. Number of species based on family characteristic

Birds have an important ecological role, including as an animal that helps pollinate flowers, scatter seeds, control pests, helps maintain a sustainable population of their predators, and food for scavenger and decomposers. Therefore, bird diversity is often used as an indicator of environmental quality (Ayat, 2011).

The diversity of bird species found at the research site was analyzed according to the IUCN Red List conservation status category, which is used by the International Union for the Conservation of Nature and Natural Resources (IUCN) in classifying the various species of living things that are threatened with extinction. The results of grouping based on IUCN status showed that all bird in the study site classified as LC or least concern or at low risk of extinction. Based on the analysis of all species found, a categorization of the Convention on International Trade in Endangered Species of Wild Fauna and Flora (CITES) was carried out (Table 1). The results showed that there were two species that fall into the Appendix II category, namely Changeable Hawk-eagle (Nisaetus cirrhatus) and Black Eagle (Ictinaetus malayensis), means that the species is not threatened with extinction unless there are continued trades without regulation. The diversity of species found at the study site was analyzed again based on the Regulation of the Minister of Environment and Forestry of the Republic of Indonesia Number P.106 / Minister of the Environment / Secretary General / Kum.1 / 12/2018. The data showed (Table 1), that there were 45 unprotected birds and 3 protected bird species. The species of birds that have protected status are Changeable Hawk-eagle (Nisaetus cirrhatus), Black Eagle (Ictinaetus malayensis), and Bluewinged Leafbird (Chloropsis moluccensis).

Based on the results of this research data revealed that the Curup Tenang area has high diversity of bird species. These data could be a source for developing tourism potentials. However, the diversity of birds in the Curup Tenang tourism area has never been studied before and has not been analyzed as a potential addition of new tourist attractions. Avitourism is a sub-sector of tourism that emerged from nature-based tourism which focuses on bird watching. Bird watching in avitourism involves multidisciplinary science, such as social science, geography, tourism, conservation, ecology, and economics (Steven et al., 2014). 


\section{JURNAL BIDDJATI}

http://journal.uinsgd.ac.id/index.php/biodjati

Table 1. Species found in tourism site of Curup Tenang, Bedegung Village

\begin{tabular}{|c|c|c|c|c|c|}
\hline Family & Common Name & Species Name & IUCN & CITES & P.106/2018 \\
\hline Accipitridae & Changeable Hawk-eagle & Nisaetus cirrhatus & $\mathrm{LC}$ & II & $\mathrm{P}$ \\
\hline Accipitridae & Black Eagle & Ictinaetus malayensis & $\mathrm{LC}$ & II & $\mathrm{P}$ \\
\hline Alcedinidae & White-breasted Kingfisher & Halcyon smyrnensis & $\mathrm{LC}$ & - & NP \\
\hline Apodidae & House Swift & Apus nipalensis & $\mathrm{LC}$ & - & NP \\
\hline Apodidae & Glossy Swiftlet & Collocalia esculenta & $\mathrm{LC}$ & - & NP \\
\hline Artamidae & White-breasted Woodswallow & Artamus leucorynchus & $\mathrm{LC}$ & - & NP \\
\hline Campephagidae & Pied Triller & Lalage nigra & $\mathrm{LC}$ & - & NP \\
\hline Capitonidae & Coppersmith Barbet & Megalaima haemacephala & $\mathrm{LCt}$ & - & NP \\
\hline chloropseidae & Blue-winged Leafbird & Chloropsis moluccensis & $\mathrm{LC}$ & - & $\mathrm{P}$ \\
\hline Columbidae & Zebra Dove & Geopelia striata & $\mathrm{LC}$ & - & NP \\
\hline Columbidae & Spotted Dove & Streptopelia chinensis & $\mathrm{LC}$ & - & NP \\
\hline Cuculidae & Lesser Coucal & Centropus bengalensis & $\mathrm{LC}$ & - & NP \\
\hline Cuculidae & Hodgson's Hawk-Cuckoo & Cuculus fugax & $\mathrm{LC}$ & - & NP \\
\hline Cuculidae & Square-tailed Drongo-cuckoo & Surniculus lugubris & $\mathrm{LC}$ & - & NP \\
\hline Cuculidae & Western Koel & Eudynamys scolopaceus & $\mathrm{LC}$ & - & NP \\
\hline Cuculidae & Plaintive Cuckoo & Cacomantis merulinus & $\mathrm{LC}$ & - & NP \\
\hline Dicaeidae & Orange-bellied Flowerpecker & Dicaeum trigonostigma & $\mathrm{LC}$ & - & NP \\
\hline Dicaeidae & Scarlet-headed Flowerpecker & Dicaeum trochileum & $\mathrm{LC}$ & - & NP \\
\hline Dicruridae & Black Drongo & Dicrurus macrocercus & $\mathrm{LC}$ & - & NP \\
\hline Estrildidae & Javan Munia & Lonchura leucogastroides & $\mathrm{LC}$ & - & NP \\
\hline Estrildidae & Scaly-breasted Munia & Lonchura punctulata & $\mathrm{LC}$ & - & NP \\
\hline Eurylaimidae & Long-tailed Broadbill & Psarisomus dalhousiae & $\mathrm{LC}$ & - & NP \\
\hline Hemiprocnidae & Grey-rumped Treeswift & Hemiprocne longipennis & $\mathrm{LC}$ & - & NP \\
\hline Hirundinidae & Pacific Swallow & Hirundo tahitica & $\mathrm{LC}$ & - & NP \\
\hline Laniidae & Long-tailed Shrike & Lanius schach & $\mathrm{LC}$ & - & NP \\
\hline Motacillidae & Grey Wagtail & Motacilla cinerea tunstall & $\mathrm{LC}$ & - & NP \\
\hline Muscicapidae & Asian Brown Flycatcher & Muscicapa dauurica & $\mathrm{LC}$ & - & NP \\
\hline Muscicapidae & Indigo Flycatcher & Eumyias indigo & $\mathrm{LC}$ & - & NP \\
\hline Nectariniidae & Brown-throated Sunbird & Anthreptes malacensis & $\mathrm{LC}$ & - & NP \\
\hline Nectariniidae & Olive-backed Sunbird & Cinnyris jugularis & $\mathrm{LC}$ & - & NP \\
\hline Nectariniidae & Long-billed Spiderhunter & Arachnothera robusta & $\mathrm{LC}$ & - & NP \\
\hline Nectariniidae & Little Spiderhunter & Arachnothera longirostra & $\mathrm{LC}$ & - & NP \\
\hline Ploceidae & Eurasian Tree Sparrow & Passer montanus & $\mathrm{LC}$ & - & NP \\
\hline Pycnonotidae & Black-capped Bulbul & Pycnonotus melanicterus & $\mathrm{LC}$ & - & NP \\
\hline Pycnonotidae & Sooty-headed Bulbul & Pycnonotus aurigaster & $\mathrm{LC}$ & - & NP \\
\hline Pycnonotidae & Yellow-vented Bulbul & Pycnonotus goiavier & $\mathrm{LC}$ & - & NP \\
\hline Sittidae & Munguk beledu & Sitta frontalis & $\mathrm{LC}$ & - & NP \\
\hline Sylvidae & Yellow-bellied Warbler & Abroscopus superciliaris & $\mathrm{LC}$ & - & NP \\
\hline Sylvidae & Ashy Tailorbird & Orthotomus ruficeps & $\mathrm{LC}$ & - & NP \\
\hline Sylvidae & Common Tailorbird & Orthotomus sutorius & $\mathrm{LC}$ & - & NP \\
\hline Sylvidae & Bar-winged Prinia & Prinia familiaris & $\mathrm{LC}$ & - & NP \\
\hline Sylvidae & Yellow-bellied Prinia & Prinia flaviventris & $\mathrm{LC}$ & - & NP \\
\hline Timaliidae & Striped Tit-Babbler & Macronous gularis & $\mathrm{LC}$ & - & NP \\
\hline Timaliidae & Horsfield's Babbler & Malacocincla sepiarium & $\mathrm{LC}$ & - & NP \\
\hline Timaliidae & Chestnut-winged Babbler & Stachyris erythroptera & $\mathrm{LC}$ & - & NP \\
\hline Turdidae & White-crowned Forktail & Enicurus leschenaulti & $\mathrm{LC}$ & - & NP \\
\hline Turnicidae & Barred Buttonquail & Turnix suscitator & $\mathrm{LC}$ & - & NP \\
\hline Zosteropidae & Indian White-eye & Zosterops palpebrosus & $\mathrm{LC}$ & - & NP \\
\hline
\end{tabular}

LC: Least Concerned; II: Appendix II; P: Protected; NP: Not Protected 


\section{JURNAL BIDDJATI}

http://journal.uinsgd.ac.id/index.php/biodjati

There are three species of birds that get attention because they have a high potential to be developed into critical objects of avitourism. The three types are the Changeable Hawk-eagle, Black Eagle, and Blue-winged Leafbird (Figure 3). These species are important species that have conservation status according to CITES and a list of species protected by the government. According to CITES, Changeable Hawk-eagle and Black Eagle are listed in Appendix II. Such conditions indicated that the species is included in the type whose population is precariously close to endangered so that its trade controls are tight and regulated by strict rules. Besides that, the Changeable Hawk-eagle, Black Eagle, and Blue-winged Leafbird are protected by the Indonesian government. Utilization of these types, especially for breeders and trade must be based on permission by the Minister of Tourism. However, as long as these species are still free in nature, utilization like avitourism is permitted.

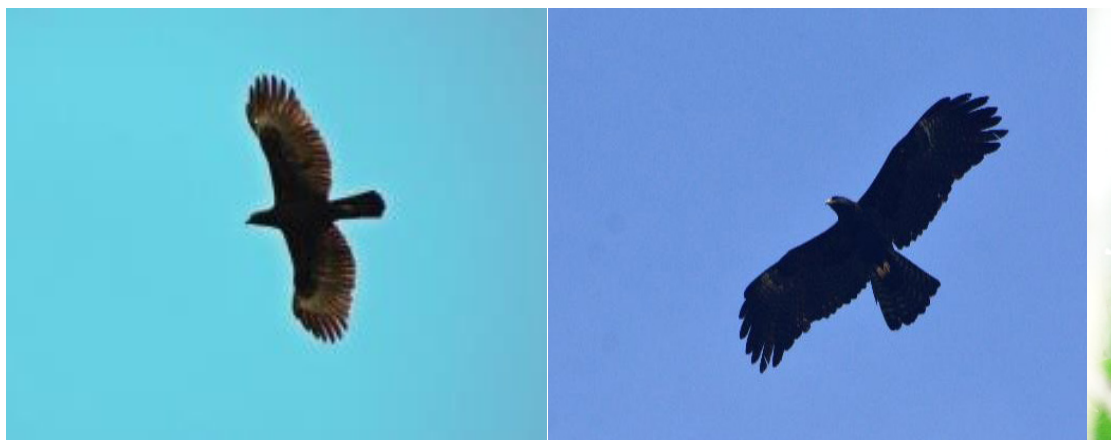

(a) (b)

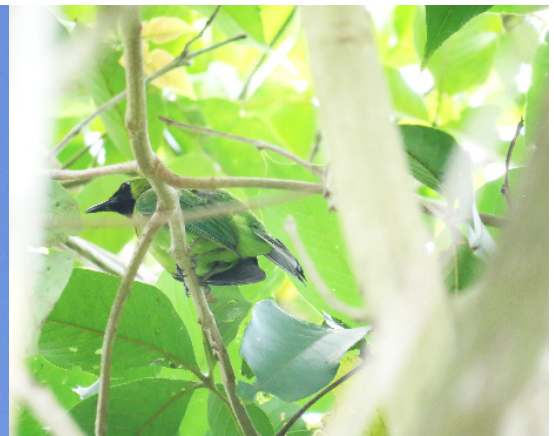

(c)

Figure 3. Species that potential as avitorism objetcs. (a) Changeable Hawk-eagle, (b) Black Eagle, and (c) Bluewinged Leafbird.

As the part of Utilization of birds as objects of tourism, managers and visitors should understand what restrictions can be applied. Therefore, managers and visitors need to know and learn in advance about the ethics of Avitourism, as the code of ethics of bird watchers showed below (Atlas Burung Indonesia, 2020):

Indonesian Bird Watcher Code of Ethics

Indonesian bird watchers are Indonesian citizens who observe wild birds, are part of nature lovers, agree on values and ethics that must be upheld, namely:

1. Realizing that birds are part of God's created nature that must be protected and preserved

2. Always maintain the safety of themselves and others involved in activities

Sitanggang et al.
3. Maintain the integrity and naturalness of the environment visited

4. Do not interfere directly or indirectly with observed birds

5. Respect local communities and their values and wisdom

6. Comply with and obey the rules that apply at the observation site

7. Upholding the value of honesty in bird watching

8. Maintain brotherly fellow bird watchers without distinguishing ethnicity, religion, race and intergroup.

(Indonesian Bird Watchers Meeting IX

Banyumas, November 2nd, 2019).

The bird watcher's ethics was agreed upon at the IX Indonesian Bird Watchers 


\section{JURNAL BIDDJATI}

http://journal.uinsgd.ac.id/index.php/biodjati

Meeting held in Banyumas in 2019. The agreement emerged in order to build understanding among bird watchers, both from researchers, environmental activists, photography hobbyists, and business entrepreneurs who have been involved in avitourism. Avitourism as one of the special interest tours has several characteristics, such as relatively inexpensive (requires binoculars, a bird's field guide book, and a camera to take photographs of birds), can be done anywhere (in various types of habitats), can be done by anyone (young and old, male and female, all levels of education) so that the target audience is broad, and increasing knowledge and insight into the environment which furthermore is expected to be able to build and increase concern for conservation, especially birds.

Avitourism activities can also be done by using a path specifically designed by the manager or a regular path that already exists at a tourist location. Pathways that can be used for avitourism activities also highly dependent on the conditions of time, weather, and daily behavior of birds. This is related to the potential emergence of birds and also the safety factor during the trip. This tour activity can also be a separate and engaging hobby for visitors. This bird-watching activity is a preferred hobby for tourists because it provides an alternative to new and exciting adventures and experience (Afif et al., 2018).

Activities that can be carried out while doing avitourism activities are observing certain types of birds or observing their behavior. Despite, it is common to carry out avitourism activities only to hunt photographs or videos of certain birds in their natural habitat. This activity can encourage people to get to know birds and their life in nature. Bird watching can also make an important contribution to the development of science and education since one of the reasons for tourists to do bird watching activity is for science and educational activity (Steven et al., 2014).

This kind of tourism activity has been carried out and continues to be developed, especially in several developed countries. Recently, avitoursm has become one of the tourist trends and popular in central Europe, Great Britain, Australia, and the United States (Manuel et al., 2011). While this tourism activity in Indonesia has the potential to become an innovation in the development of a natural tourism area. In fact, it is not just a tourist activity. For the management of this tour can be included in a natural tourism industry development that is implemented as a business.

Avitourism managers also need to divide the types of bird watchers based on their level of interest. This category of applicants will determine he type of model that will beoffered to visitors. According to (Jones et al., 2002), the category of bird watchers needs to be divided in order to make it easier when preparing what forms of observation tourism. The category is arranged based on one's level of specialization or knowledge of this type of tour, motivation and logistical constraints.

The first category is general birdwatcher. This observer is a bird watcher who only wants to try other forms of nature tourism and outdoor recreation while traveling, such as wild birds. The second category is the limited budget specialist bird watcher. This category is the earliest classification of observers. The next is aserious observer that have their own motivation for the satisfaction of observing wild birds in nature, but this observer is still limited by their personal funds available.

The next category is the specialist bird watchers who are willing to pay to see more birds. Observers with this category are those who have little time for birdwatching tours because of their busy schedule. But with their personal funds available, they are willing to 


\section{JURNAL BIDDJATI}

http://journal.uinsgd.ac.id/index.php/biodjati

pay for a guide at an observation site that has been managed with a certain fee that is adjusted to the length of time of their observation. Usually, observers with this category want to meet with a type of bird accompanied by a field guide.

The last category of bird watchers is the specialist bird watchers who need packages from tour managers. Usually, this category also wants packages with facilities, such as bird watcher equipment, trained guides, lodging, and also local accommodation. But the observer is willing to pay more to get satisfaction both from the tour program and in terms of the facilities offered.

Based on the potential of bird diversity that Curup Tenang has, the development of this tourism site can be directed to a service that offers some packages of tourism activity. These 48 bird species were found with the uniqueness that can attract tourists if a suitable package is offered. In addition, visitors can also be offered to do avitourism activities such as experimenting the phenomenon of migration behavior, social and unique mating behavior, or exploration of important bird species (endemic species or birds with endangered, threatened, and legally protected status.). These packages could contain pieces of information and educational aspect regarding the birds. Visitors tend to spend their time in the tourism site not only for recreation but also to receive some educational value (Afif et al., 2018). In addition, photography and binocular rent services, a well-informed guide, maps, guidebook of birds, foods and beverages, an even a lodge could be included in the packages to increase the convenience for the visitors.

In fact, tourists who visit the Curup Tenang site can be categorized as general bird watchers. This is related to the fact that Curup Tenang is a newly developed tourism site. That means the visitors are not speciali- zed yet. This condition can be beneficial for the developer of Curup Tenang to start a special tourism activity (avitourism) as the main value of the site. Developers can design some performance mechanism that demonstrates the attractiveness of birds in Curup Tenang, besides exploring their natural habitat.

This study showed that the diversity of bird in Curup Tenang is dominated by insect-eating birds (insectivore). This condition will facilitate the developer to design some mechanism which gathers birds in certain spots, for example creating a box full of common insect to attract birds to come. This will help the visitor to watch the birds more easily, and watch their uniqueness and their behavior. Combined with excellent service packages, these performance methods will gain the visitor's satisfaction. The service quality provided by the site developer and management related to a positive impact on visitor satisfaction, destination image, and destination loyalty (Kumar et al., 2019).

The concept of excellent service and management on bird watching activity will provide a good impression for the visitor to avitourism. The development of a sustainable avitourism industry requires appropriate infrastructure for tourism activities, such as proper tracking path, comfort visitor shelter, and well-maintained tourism site (Steven et al., 2014, Afif et al., 2018). The lack of human resources such as local guide's lack of knowledge about birds, limited previous exposure to tourism and visitors, the guide's lack of self-assurance, can also be troublesome challenges that require sustained mentorship and support (Biggs et al., 2011). On the other side, cultural differences and vandalism are also common problems in the tourism site. The developer must be concerned to prevent vandalism from the visitors and design strict rules regarding this issue. Vandalism and lack 


\section{JURNAL BIDDJATI}

http://journal.uinsgd.ac.id/index.php/biodjati

of awareness from visitors will have direct impacts on birds and their habitat in Curup Tenang. This kind of action will disturb the birds and force them to leave for safer places.

This study concluded that The Curup Tenang area contained a high diversity of bird species. These data could be a source for developing tourism potentials. Birds found during the study were 48 species consisting of 27 families. There are three species of birds that get attention because the three types are types that have high potential to be developed into critical objects of avitourism. The three types are the Changeable Hawk-eagle, Black Eagle, and Blue-winged Leafbird.

\section{ACKNOWLEDGEMENTS}

The author expresses gratitude to Dinas Lingkungan Hidup Provinsi Sumatera Selatan for granting permission to the site so that this research can be carried out. Also to PT PGN (Persero) Tbk for the support provided to conduct research. Authors also acknowledge Institut Teknologi Sumatera, in particular the Biology Study Program and the Center for Coastal and Ocean Resources Study of the IPB University.

\section{REFERENCES}

Afif, F., Aisyianita, R. A. \& Hastuti, S. D. S. (2018). Potensi Birdwatching sebagai Salah Satu Daya Tarik Wisata di Desa Wisata Jatimulyo, Kecamatan Girimulyo, Kabupaten Kulonprogo. Jurnal Media Wisata, 16(2), 1007-1015.

Atlas Burung Indonesia. (2020). Kode Etik. Retrieved from http://atlasburung.web. $\mathrm{id} /$ pengabdi/kode-etik/.

Ayat, A. (2011). Burung-Burung Agroforest di Sumatera. Bogor: World Agroforestry Centre.
Biggs, D., Turpie, J., Fabricius, C. \& Spenceley, A. (2011). The Value of Avitourism for Conservation and Job Creation-An analysis from South Africa. Conservation and Society, 9(1), 80-90.

Buckley, R. (2011). Tourism and Environment. Annual Review of Environment and Resources, 36, 394-416.

Jones, B. D. N., Buckley, R., Higginbottom, K., Rann, M. K. \& Davis, A. P. D. (2002). Birdwatching Tourism in Queensland. 10, 1-46.

Kumar, M. D., Govindarajo, N. S. \& Khen, M. H. S. (2019). Effect of Service Quality on Visitor Satisfaction, Destination Image and Destination Loyalty - Practical, Theoretical and Policy Implications to Avitourism. International Journal of Culture, Tourism and Hospitality Research, 14(1), 83-101.

Lee, C. K., Lee, J. H., Mjelde, J. W., Scott, D. \& Kim, T. K. (2009). Assessing the Economic Value of a Public Birdwatching Interpretative Service using a Contingent Valuation Method. International Journal of Tourism Research, 11(6), 583-593.

Liu, J., Bai, H., Ma, H. \& Feng, G. (2019). Bird Diversity in Chinese Urban Parks was More Associated with Natural Factors than Anthropogenic Factors. Urban Forestry \& Urban Greening, 43(9).

Lonn, P., Mizoue, N., Ota, T., Kajisa, T. \& Yoshida, S. (2018). Evaluating the Contribution of Community-based Ecotourism (CBET) to Household Income and Livelihood Changes: A Case Study of the Chambok CBET Program in Cambodia. Ecological Economics, 151, 6269.

Manuel, J., Mogollón, H., María, A., Cerro, C., María, J. \& Durán, G. (2011). Proposals for the Development and Com- 


\section{JURNAL BIDDJATI}

http://journal.uinsgd.ac.id/index.php/biodjati

mercialization of Birdwatching Tourism in Extremadura. Cuadernos de Turismo, 28(28), 243-245.

Mardalis. (2008). Metode Penelitian. Suatu Pendekatan Proposal. Jakarta: PT Bumi Aksara.

Morelli, F., Pruscini, F., Santolini, R., Perna, P., Benedetti, Y. \& Sisti, D. (2013). Landscape Heterogeneity Metrics as Indicators of Bird Diversity: Determining the Optimal Spatial Scales in Different Landscapes. Ecological Indicators, 34, 372-379.

Sriarkarin, S. \& Lee, C. H. (2018). Integrating Multiple Attributes for Sustainable Development in a National Park. Tourism Management Perspectives, 28(1), 113-125.

Steven, R., Morrison, C. \& Castley, J. G. (2014). Birdwatching and Avitourism: a Global Review of Research into its Participant Markets, Distribution and Impacts, Highlighting Future Research Priorities to Inform Sustainable Avitourism Management. Journal of Sustainable Tourism, 23(8-9), 1257-1276.
Tseng, M. L., Lin, C., Remen Lin, C. W., Wu, K. J. \& Sriphon, T. (2019). Ecotourism Development in Thailand: Community Participation Leads to the Value of Attractions using Linguistic Preferences. Journal of Cleaner Production, 231, 1319-1329.

Yan, L., Gao, B. W. \& Zhang, M. (2017). A Mathematical Model for Tourism Potential Assessment. Tourism Management, 63, 355-365. 